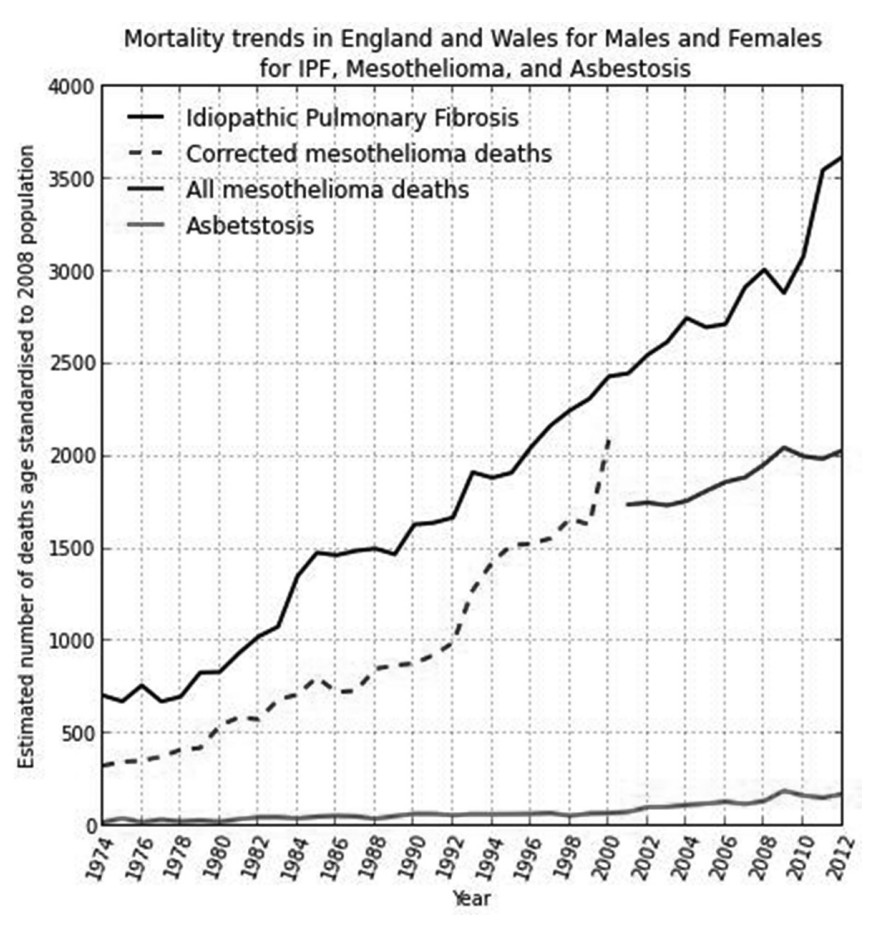

Abstract S3 Figure 1

Conclusions New antifibrotic treatments for IPF throw into sharp focus the question of whether or not a proportion of IPF is due to occult asbestos exposure; patients known to have asbestos exposure are currently not considered to be candidates for antifibrotic treatments. Our data are consistent with a proportion of IPF being attributable to asbestos exposure but are not conclusive and further research is needed.

\section{S4 RELATIONSHIP BETWEEN HISTORIC UK ASBESTOS IMPORTS AND ANNUAL MORTALITY DUE TO MESOTHELIOMA, ASBESTOSIS AND IDIOPATHIC PULMONARY FIBROSIS}

CM Barber, RE Wiggans, D Fishwick. Centre for Workplace Health, Health and Safety Laboratory, Buxton, UK

\subsection{6/thoraxjnl-2014-206260.10}

Background Previous studies from a number of countries have demonstrated that the rising mortality due to mesothelioma and asbestosis can be predicted from their historic asbestos usage. Mortality due to idiopathic pulmonary fibrosis (IPF) is also rising in the UK, without any identified explanation. This analysis compared annual male and female mortality due to IPF, asbestosis and mesothelioma, and examined the relationship between mortality and national asbestos import data.

Methods Mortality data for IPF and asbestosis in England and Wales were available from the Office for National Statistics (ONS). Data for mesothelioma deaths in England and Wales and historic UK asbestos import data were available from the Health and Safety Executive (HSE). The numbers of annual deaths due to each condition were plotted separately by gender, against UK asbestos imports 48 years earlier. Pearson correlation co-efficients were then calculated.

Results Correlation co-fficients for each condition are shown in Table 1. The annual number of deaths due to mesothelioma and IPF were significantly correlated with historical asbestos imports
Abstract S4 Table 1 Correlation co-efficients for historic national asbestos import data, plotted against annual mortality due to mesothelioma, asbestosis, and idiopathic pulmonary fibrosis (IPF)

\begin{tabular}{llll}
\hline & Mesothelioma & Asbestosis & IPF \\
\hline Male & $0.96(p<0.001)$ & $0.87(p<0.001)$ & $0.96(p<0.001)$ \\
Female & $0.94(p<0.001)$ & $-0.15(p=0.32)$ & $0.97(p<0.001)$ \\
\hline
\end{tabular}

for both genders. For asbestosis mortality, a similar relationship was found for male but not female deaths.

Conclusion The strength of the association between IPF and historical asbestos imports was similar to that seen for mesothelioma mortality. This finding suggests that the role of occupational and environmental asbestos exposure in the aetiology of IPF requires further consideration.

\section{S5 PREVALENCE OF IGE SENSITISATION TO 'IMPROVER MIX' ENZYMES AMONG SYMPTOMATIC BAKERS WORKING IN UK SCRATCH BAKERIES}

${ }^{1} M$ Jones, ${ }^{1} \mathrm{~J}$ Welch, ${ }^{1} \mathrm{~J}$ Turvey, ${ }^{2} \mathrm{~J}$ Cannon, ${ }^{2} \mathrm{~B}$ Fitzgerald, ${ }^{1} \mathrm{~J}$ Szram, ${ }^{1} \mathrm{P}$ Cullinan. ${ }^{1}$ Imperial College, London, UK; ${ }^{2}$ Royal Brompton and Harefield NHS Trust, London, UK

\subsection{6/thoraxjn-2014-206260.11}

Introduction and objectives Bakers working in supermarket scratch bakeries in the UK are exposed not only to flour and fungal alpha amylase but also other enzymes, incorporated in a pre-mixed bag of 'dough improvers'. Bakers and their employers are usually unaware of which enzymes are being used within the 'improver mix'. We have examined the question of whether supermarket bakers develop sensitisation to 'improver mix' enzymes other than fungal alpha amylase.

Abstract S5 Table 1 Sensitisation to 'improver mix' enzyme in bakers stratified by sensitisation to either flour and/or alpha amylase

\begin{tabular}{|c|c|c|c|c|}
\hline \multirow[b]{2}{*}{$\begin{array}{l}\text { 'Improver } \\
\text { enzyme' } \\
\text { used in } \\
\text { bakery }\end{array}$} & \multirow[b]{2}{*}{$\begin{array}{l}\text { Quantity of } \\
\text { enzyme } \\
\text { used } \\
\text { in 'improver } \\
\text { mix' } \\
\text { (ppm) }\end{array}$} & \multicolumn{3}{|c|}{ Sensitisation to 'improver mix' enzyme } \\
\hline & & $\begin{array}{l}\text { All } \\
\text { bakers* }\end{array}$ & $\begin{array}{l}\text { Bakers } \\
\text { co-sensitised } \\
\text { to flour and/or } \\
\text { alpha } \\
\text { amylase* }\end{array}$ & $\begin{array}{l}\text { Bakers } \\
\text { not-sensitised } \\
\text { to flour and/or } \\
\text { alpha } \\
\text { amylase* }\end{array}$ \\
\hline Maltogenic & & $12 / 260$ & $10 / 84$ & $2 / 176$ \\
\hline \multirow[t]{2}{*}{ amylase } & $40-50$ & $(5 \%)$ & $(12 \%)$ & $(1 \%)$ \\
\hline & & $11 / 119$ & $8 / 26$ & $3 / 93$ \\
\hline Cellulase & 25 & $(9 \%)$ & $(31 \%)$ & $(3 \%)$ \\
\hline \multicolumn{5}{|l|}{ Fungal Xylanase } \\
\hline & & $40 / 260$ & $36 / 84$ & $4 / 176$ \\
\hline & 20 & $(15 \%)$ & $(43 \%)$ & $(2 \%)$ \\
\hline & 4 & $32 / 141$ & $31 / 58$ & $1 / 83$ \\
\hline \multirow[t]{2}{*}{ Fungal Xylanase } & X 5 conc & $(23 \%)$ & $(53 \%)$ & $(1 \%)$ \\
\hline & & $25 / 260$ & $24 / 84$ & $1 / 176$ \\
\hline \multirow[t]{2}{*}{ Lipase } & 20 & $(10 \%)$ & $(29 \%)$ & $(0.6 \%)$ \\
\hline & & $35 / 260$ & $35 / 84$ & $0 / 176$ \\
\hline \multirow[t]{2}{*}{ Bacterial Xylanase } & 10 & $(13 \%)$ & $(42 \%)$ & $(0 \%)$ \\
\hline & & $32 / 260$ & $30 / 84$ & $2 / 176$ \\
\hline \multirow[t]{2}{*}{ Fungal $\alpha$-amylase } & 10 & $(12 \%)$ & $(36 \%)$ & $(1 \%)$ \\
\hline & & $29 / 260$ & $27 / 84$ & $2 / 176$ \\
\hline Glucose Oxidase & $5-10$ & $(11 \%)$ & $(32 \%)$ & $(1 \%)$ \\
\hline Bacterial & & $15 / 260$ & $4 / 26$ & $1 / 93$ \\
\hline$\alpha$-amylase & 0.5 & $(6 \%)$ & $(17 \%)$ & $(0.6 \%)$ \\
\hline
\end{tabular}

